\title{
Analisis Reliabilitas dan Responsivitas dalam Pelayanan Penanggulangan Bencana Alam Kebakaran pada Badan Penanggulangan Bencana Daerah di Kabupaten Aceh Singkil
}

\section{Analysis of Reliability and Responsiveness in Fire and Natural Disaster Management Services at the Regional Disaster Management Agency in Aceh Singkil Regency} Abidah Manik ${ }^{1}$, Heri Kusmanto ${ }^{2}$ \& Maksum Syahri Lubis ${ }^{3}$

1) Magister Program Studi Administrasi Publik, Universitas Medan Area, Indonesia

2) Departemen Ilmu Politik, Fakultas Ilmu Sosial dan Ilmu Politik,

Universitas Sumatera Utara, Indonesia

3) Program Studi Administrasi Publik, Fakultas Ilmu Sosial dan Ilmu Politik, Universitas Medan Area, Indonesia

\footnotetext{
Abstrak

Tujuan penelitian ini adalahmenganalisis reliabilitas dan responsivitas Badan Penanggulangan Bencana Daerah (BPBD) dalam penanggulangan bencana kebakaran di Kabupaten Aceh Singkil. Bentuk penelitian yang digunakan adalah penelitian kualitatif yang bersifat deskriptif. Berdasarkan hasil penelitian dan pembahasan disimpulkan realibilitas dan responsivitas BPBD Kabupaten Aceh Singkil dalam penanggulangan kebakaran belum baik. Beberapa hal yang disarankan antara lain melakukan pelatihan bagi pegawai honor, menambahkan jumlah posko pemadam kebakaran, menjalin kerjasama dengan instansi lain terkait ketersediaan air serta lebih memperhatikan dan menanggapi keluhan masyarakat. Kendala umum yang sering dialami BPBD Kabupaten Aceh Singkil pada saat terjadi kebakaran adalah kesulitan dalam upaya penanganannya di lapangan diantaranya keterbatasan jumlah air dan sumber air di lokasi kebakaran, tidak tersedianya fasilitas pemadaman kebakaran di lingkungan dan pada bangunan, serta respon dari unit pemadam kebakaran yang kadang terlambat tiba di lokasi dikarenakan jauhnya jarak tempuh dan kondisi lalu lintas.

Kata Kunci: kualitas, responsivitas, reliabilitas, penanggulangan bencana kebakaran
}

\begin{abstract}
The purpose of this study is to analyze the reliability and responsiveness of the Regional Disaster Management Agency (BPBD) in the management of fire disasters in Aceh Singkil Regency. The form of research used is descriptive qualitative research. Based on the results of research and discussion, it can be concluded that the reliability and responsiveness of $B P B D$ of Aceh Singkil Regency in fire prevention has not been good. Some things that were suggested include training for honorarium employees, adding the number of fire brigade posts, collaborating with other agencies regarding water availability and paying more attention and responding to community complaints. A common obstacle often experienced by BPBD Aceh Singkil Regency during a fire is difficulties in its handling efforts in the field including the limited amount of water and water sources at the location of the fire, the unavailability of fire fighting facilities in the environment and on buildings, as well as the response from fire fighting units that sometimes arrived late at the location due to the distance and traffic conditions.
\end{abstract}

Keywords: quality, responsiveness, reliability, fire disaster management

How to Cite: Manik A, Kusmanto H \& Lubis M.S (2020). Analisis Reliabilitas dan Responsivitas dalam Pelayanan Penanggulangan Bencana Alam Kebakaran pada Badan Penanggulangan Bencana Daerah di Kabupaten Aceh Singkil. Strukturasi: Jurnal Ilmiah Magister Administrasi Publik, 1(1) 2020: 65-74,

*E-mail: abdullahafifudin@gmail.com

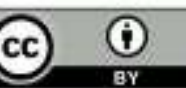




\section{PENDAHULUAN}

Bahaya kebakaran bagi sebagian orang merupakan kejadian bahaya yang dianggap ringan akan tetapi pada dasarnya kebakaran adalah bahaya yang besar dan serius. Kebakaran bisa terjadi karena unsur teknis maupun non teknis. Bahaya kebakaran merupakan bahaya yang besar dan serius karena dampak yang ditimbulkan sangat besar, bisa berupa kerugian materil, moril bahkan korban jiwa. Pengertian kebakaran menurut Adzim, Hebbie Ilma (2013) adalah nyala api baik kecil maupun besar pada tempat, situasi dan waktu yang tidak dikehendaki yang bersifat merugikan dan pada umumnya sulit untuk dikendalikan. Nyala api disebabkan beberapa unsur diantaranya panas, oksigen, dan bahan mudah terbakar yang menghasilkan panas dan cahaya. Adapun penyebab umum terjadinya kebakaran dikarenakan tiga faktor yaitu faktor manusia, faktor teknis dan faktor alam dan bencana alam. Resiko kebakaran dapat terjadi kapan dan dimana saja, tidak mengenal waktu akan terjadinya bencana tersebut.

Potensi bahaya kebakaran merupakan suatu keadaan yang memungkinkan atau berpotensi terhadap terjadinya kebakaran baik sebagai bencana alam ataupun bencana yang disebabkan oleh perbuatan manusia itu sendiri yang menyebabkan kerugian, kematian, kerusakan atau ketidakmampuan melaksanakan fungsi operasional yang telah ditetapkan (Tarwaka, 2012). Kerugian besar yang diakibatkan oleh kebakaran dapat diminimalisir dengan mengetahui tingkat kerentanan kebakaran permukiman, persebaran dan luasannya dapat di analisa sehingga penanggulangannya dapat dilakukan secara efektif dan efisien (Ramadhan \& Matondang, 2016; Nugraha \& Sulastri, 2018; Koteng, 2012; Rambe, Purba\& Tarigan, 2016).

Selain kebakaran permukiman, salah satu wilayah yang berpotensi terjadi kebakaran adalah hutan dan lahan yang terjadi baik alami maupun oleh perbuatan manusia, yang ditandai dengan penjalaran api dengan bebas serta mengkonsumsi bahan bakar hutan dan lahan yang dilaluinya (Adinugroho, 2004). Bencana kebakaran hutan dan lahan merupakan permasalahan serius yang harus dihadapi bangsa Indonesia hampir setiap tahun pada musim kemarau. Kebakaran hutan ini menjadi penyebab kerusakan hutan yang paling merugikan karena dalam waktu yang singkat dapat menimbulkan kerugian, baik secara ekonomis, ekologi, estetika, maupun politik.

Kebakaran hutan dan lahan di Indonesia ini merupakan permasalahan yang rutin terjadi setiap tahun khususnya pada musim kemarau. Kejadian ini tentu sudah menjadi issu penting dan merupakan sebuah rutinitas yang menghabiskan APBN dan APBD yang cukup besar jumlahnya untuk pemadaman kebakaran. Belum lagi jika dihitung dampak kesehatan terhadap jutaan masyarakat yang terkena dampak dari asap yang ditimbulkan.

Kebakaran merupakan salah satu jenis bencana yang cukup potensial dengan meninggalkan kerugian yang besar jika tidak mendapatkan perhatian dan penanganan yang cukup dalam upaya mitigasi bencana. Menurut Undang-Undang Nomor 24 Tahun 2007 tentang Penanggulangan Bencana, kebakaran termasuk kepada jenis bencana alam sekaligus bencana nonalam berdasarkan penyebab terjadinya. Hal tersebut mengindikasikan bahwa bencana kebakaran, selain dipengaruhi oleh kondisi fisik atau yang bersifat alamiah juga dapat terjadi akibat kelalaian manusia sebagai penyebabnya. 
Dalam mitigasi bencana, selain aspek fisik (alamiah) ternyata aspek manusia (sosial) pun harus mendapatkan perhatian khusus.

Kabupaten Aceh Singkil adalah salah satu kabupaten di Provinsi Aceh yang merupakan pemekaran dari Kabupaten Aceh Selatan dan sebagian wilayahnya berada di kawasan Taman Nasional Gunung Leuser. Kabupaten ini terdiri dari dua wilayah; yakni daratan dan kepulauan. Kabupaten Aceh Singkil merupakan satu-satunya daerah yang tertinggal dan termiskin di Provinsi Aceh yang ditetapkan oleh Presiden Joko Widodo melalui Peraturan Presiden Nomor 131 Tahun 2015 tentang Penetapan Daerah tertinggal Tahun 2015-2019.

Meski disebut sebagai daerah termiskin dan tertinggal. Akan tetapi saat ini belasan perusahaan kelapa sawit telah beroperasi di Kabupaten yang dimekarkan dari Aceh selatan ini, mengelola lahan puluhan ribu hektar. Keberadaan perkebunan sawit di Aceh singkil, selain kurang berpengaruh terhadap peningkatan ekonomi daerah juga merusak hutan rawa gambut yang ada. Banyak perusahaan yang menanam sawit di lahan gambut dan melakukan pembersihan lahan dengan cara pembakaran sehingga berpotensi terhadap kebakaran hutan dan lahan.

Hal ini menyebabkan Aceh Singkil menjadi daerah yang rawan terhadap kebakaran hutan dan lahan terutama sekali pada saat musim kemarau, baik yang disebabkan oleh kelalaian masyarakat maupun kelalaian pihak perusahaan di samping kebakarankebakaran yang disebabkan oleh faktor-faktor lain seperti kebakaran rumah hunian atau yang lainnya.

Selain bencana kebakaran, Aceh Singkil juga termasuk salah satu daerah yang rawan bencana alam banjir, dimana masyarakat sering harus mempergunakan sampan sebagai satu-satunya transportasi yang dapat dipakai sebagai penghubung daerah karena hanya memiliki satu akses jalan darat yang apabila terkena banjir maka tidak dapat dilalui dengan kendaraan bermotor baik roda dua maupun roda empat.

Pemerintah Kabupaten Aceh Singkil, sebagai salah satu organisasi pemerintah dalam kerangka pemberian pelayanan publik kepada masyarakat maka tugas pelayanan publik dalam rangka menanggulangi bencana kebakaran ditugaskan kepada Badan Penanggulanan Bencana Daerah yang disingkat BPBD (Damanik et .all, 2018).

Sesuai dengan Peraturan Bupati Aceh Singkil Provinsi Aceh Nomor 51 Tahun 2016 tentang Kedudukan, Susunan Organisasi, Tugas Fungsi dan Tata Kerja Badan Penanggulangan bencana Daerah Aceh Singkil, maka BPBD di kepalai langsung oleh Sekretaris daerah sedangkan sebagai unsur pelaksana ditunjuk dengan keputusan adalah seorang Kepala Pelaksana BPBD yang disingkat "Kalak".

Kepala Pelaksana dibantu oleh seorang sekretaris yang membawahi 3 (tiga) Sub Bagian dan Kepala Pelaksana juga membawahi 3 (tiga) Bidang yaitu: Bidang Pencegahan dan Kesiap Siagaan; Bidang Kedaruratan dan Logistik; dan Bidang Rehabilitasi dan Rekonstruksi.

Pemadam Kebakaran (Damkar), yang mempunyai tugas dan tanggung jawab utama melakukan kegiatan persiapan, pencegahan, dan penanganan yang berkaitan dengan kebakaran berada di bawah seksi pemadam kebakaran di bidang Kedaruratan dan Logistik. 
Ada 4 (Empat) kecamatan di wilayah Aceh singkil yang belum memiliki armada pemadam kebakaran, 2 (dua) diantaranya yaitu Kecamatan Pulau Banyak dan Kecamatan Pulau Banyak Barat berada di wilayah kepulauan, lebih membutuhkan selang pemadam kebakaran (fire hose) sebagai sarana untuk memadamkan kebakaran sedangkan 2 (dua) wilayah lain yaitu Kecamatan Kuala Baru dan Kecamatan Danau Paris berada di daratan namun untuk wilayah Kecamatan Kuala Baru relatif lebih membutuhkan fire hose sebagai sarana pemadam kebakaran karena wilayahnya berada antara lautan dan sungai.

\section{METODE PENELITIAN}

Berdasarkan masalah yang diangkat dalam penelitian yang menekankan pada proses dan makna, maka bentuk penelitian yang digunakan adalah penelitian kualitatif yang bersifat deskriptif yang bermaksud memberikan gambaran masalah secara sistematis, cermat, rinci dan mendalam mengenai kondisi pelayanan yang diberikan oleh Badan Penanggulangan Bencana Daerah Kabupaten Aceh Singkil ketika menanggulangi bencana kebakaran di Aceh Singkil (Efridawati \& Lubis, 2015).

Menurut Sutopo (2002) penelitian kualitatif lebih menekankan pada makna, lebih memfokuskan pada data kualitas dengan analisis kualitatifnya. Dengan kata lain penelitiam kualitatif lebih mementingkan makna, tidak ditentukan oleh kuantitasnya, tetapi lebih ditentukan oleh proses terjadinya dan cara memandang atau perspektifnya.

Bentuk penelitian ini mengupayakan pencarian data yang berupa kata-kata dalam susunan kalimat atau gambar yang berlanjut pada analisis data untuk memberikan gambaran yang sesuai dengan keadaan yang nyata tentang permasalahan yang ada. Menurut Nasir (1988) metode penelitian deskriptif adalah suatu penelitian yang bertujuan untuk membuat deskripsi, gambaran atau lukisan secara sistematis, factual dan akurat mengenai fakta-fakta, sifat-sifat serta hubungan antara fenomena yang diselidiki.

Dalam penelitian ini penulis berupaya menggambarkan bagaimana langkah yang dilakukan oleh Badan Penanggulangan Bencana Daerah Kabupaten Aceh Singkil dalam upaya pemberian pelayanan dalam menanggulangi bencana kebakaran di Kabupaten Aceh Singkil melalui data yang dikumpulkan melalui wawancara berupa kalimat atau gambar yang memiliki arti.

Dengan adanya penelitian ini, peneliti dapat menggambarkan secara terperinci tentang proses penanggulangan bencana di Kabupaten Aceh Singkil terutama mengenai penanggulangan bencana kebakaran. Penelitian kualitatif adalah penelitian yang bermaksud untuk memahami fenomena tentang apa yang dialami oleh subjek penelitian, misalnya perilaku, persepsi, motivasi, tindakan, dan lain lain secara holistik dan dengan cara deskriptif dalam bentuk kata kata dan bahasa pada suatu konteks khusus yang alamiah dan dengan memanfaatkan berbagai metode alamiah (Moleong 2007)

Moleong (2010) mendeskripsikan subjek penelitian sebagai informan, yang artinya orang yang dimanfaatkan untuk memberikan informasi tentang situasi dan kondisi tempat penelitian. Menurut Hendarso (dalam Suyanto, 2005) informan penelitian ini meliputi tiga macam yaitu: Informan kunci (key informan), yaitu mereka yang 
mengetahui dan memiliki berbagai informasi pokok yang diperlukan dalam penelitian. Informan utama, yaitu mereka yang terlibat secara langsung dalam interaksi sosial yang diteliti. Informan tambahan, yaitu mereka yang dapat memberikan informasi walaupun tidak langsung terlibat dalam interaksi sosial yang diteliti.

Berdasarkan uraian di atas, maka informan ditentukan dengan tidak didasarkan pedoman atau berdasarkan perwakilan populasi, namun berdasarkan kedalaman informasi yang dibutuhkan, yaitu dengan menemukan informan kunci yang kemudian akan dilanjutkan pada informan lainya dengan tujuan mengembangkan dan mencari informasi sebanyak-banyaknya yang berhubungan dengan permasalahan penelitian.

Dalam hal ini yang dijadikan sebagai informan pada penelitian ini adalah yang telah mewakili dan disesuaikan dengan perananannya dalam penanggulangan bencana daerah di Kabupaten Aceh Singkil untuk khususnya bencana kebakaran. Maka dalam penelitian ini digunakan informan yang terdiri dari:

Informan kunci, berjumlah 5 (lima) orang yaitu Sekretaris BPBD, Kabid Pencegahan dan Kesiap Siagaan, Kabid Kedaruratan dan Logistik dan Pemadam Kebakaran, Kasi Pencegahan, Kasi Kesiap Siagaan. Informan utama, berjumlah 7 (tujuh) orang, yaitu: korban bencana kebakaran di wilayah Kabupaten Aceh Singkil. Informan tambahan, berjumlah 5 (lima) orang, yaitu: tokoh masyarakat Kabupaten Aceh Singkil.

Adapun teknik pengumpulan data yang digunakan dalam penelitian ini adalah, Studi Lapangan, yaitu dengan mengamati dengan mengunjungi Badan Penanggulangan Bencana Daerah Kabupaten Aceh Singkil untuk mengetahui proses pelaksanaan penanggulangan bencana khususnya bencana kebakaran, kondisi sarana dan prasarana yang tersedia, pemanfaatan teknologi informasi yang telah digunakan dalam upaya meningkatkan kualitas penanggulangan kebakaran. Adapun studi lapangan ini terdiri dari:

Observasi partisipatif, yaitu peneliti terlibat dengan kegiatan sehari-hari orang yang sedang diamati atau yang digunakan sebagai sumber data penelitian. Sambil melakukan pengamatan, peneliti ikut melakukan apa yang dikerjakan oleh sumber data. Dengan observasi partisipan ini, maka data yang diperoleh akan lebih lengkap, akurat, dan sampai mengetahui pada tingkat makna dari setiap perilaku yang tampak.

Wawancara, melakukan tanya jawab dengan narasumber yang mengetahui dan memahami lebih jauh khususnya mengenai proses penanggulangan bencana kebakaran di Kabupaten Aceh Singkil. Studi Pustaka, yaitu dengan membaca dan mencari bukubuku yang berhubungan langsung dengan reliabilitas dan responsivitas penanggulangan bencana serta kebijakan pemerintah khususnya mengenai penanggulangan bencana kebakaran.

Dokumentasi merupakan pengumpulan data dengan cara menelaah dokumendokumen resmi dan arsip-arsip dari Badan Penanggulangan Bencana Daerah Kabupaten Aceh Singkil yang berkaitan dengan proses pelaksanaan dan penerbitan dokumen. Teknik pengumpulan data ini digunakan untuk mendukung dan melengkapi data yang telah terkumpul dari beberapa teknik penggalian data sebelumnya. 


\section{HASIL DAN PEMBAHASAN}

Kualitas pelayanan publik merupakan usaha untuk memenuhi segala sesuatu yang berhubungan dengan produksi, jasa, manusia, proses, lingkungan, dan yang menjadi kebutuhan serta keinginan konsumen baik itu berupa barang dan jasa yang diharapkan dapat memenuhi harapan dan kepuasan masyarakat sebagai pelanggan. Kualitas

secara umum harus memenuhi harapan-harapan pelanggan dan memuaskan kebutuhan mereka. Namun, demikian meskipun definisi ini berorientasi pada pengguna layanan, tidak berarti bahwa dalam menentukan kualitas pelayanan penyedia jasa pelayanan harus menuruti semua keinginan konsumen. Kualitas pelayanan dapat diketahui dengan cara membandingkan persepsi pengguna layanan atas pelayanan yang mereka terima dengan pelayanan yang sesungguhnya mereka harapkan (Rinaldi, 2012; Sirait, 2011).

Pelayanan yang berkualitas dapat dinilai dari dimensi-dimesi pelayanan sebagai berikut, dari dimensi tangibles yang meliputi fasilitas fisik, perlengkapan, pegawai, dan sarana komunikasi pada Badan Penanggulangan Bencana Daerah Kabupaten Aceh Singkil berdasarkan penelitian awal yang penulis lakukan bahwa BPBD Kabupaten Aceh Singkil dalam menanggulangi kebakaran terlihat belum baik dimana hanya memiliki 10 unit mobil pemadam kebakaran untuk penanggulangan kebakaran di 11 Kecamatan, dan tidak semua kecamatan di Kabupaten Aceh Singkil memiliki mobil pemadam dan petugas kebakaran (Hidayat et .all,2013; Nasution et .all, 2014). Keterbatasan jumlah air dan sumber air di lokasi kebakaran juga menjadi kekurangan BPBD dalam penanggulangan bencan kebakaran di Kabupaten Aceh Singkil.

Dimensi lain dalam mengetahui kualitas pelayanan adalah assurance yang mencakup kemampuan, kesopanan, bebas dari bahaya resiko atau keraguan dalam penanggulangan bencana kebakaran di Kabupaten Aceh Singkil sudah cukup baik, namun petugas masih didominasi pegawai honor yang belum mampu menjalankan standar pelayanan penanggulangan bencana kebakaran yang sesuai dengan peraturan. Sedangkan emphaty yang mencakup kemudahan dalam melakukan hubungan komunikasi baik dan memahami kebutuhan masyarakat sudah tergolong baik.

Dari dimensi yang menjadi fokus penelitian ini yaitu dimensi reliabilitas yang merupakan kemampuan penyedia layanan untuk memberikan pelayanan sesuai yang dijanjikan secara tepat dan terpercaya. Reliabilitas atau kehandalan pegawai dalam memberikan pelayanan sangat membantu masyarakat dalam menerima pelayanan dengan cepat dan mudah. Kehandalan dapat dilihat dari kecermatan dalam melayani, kemampuan dan keahlian pegawai dalam menggunakan alat bantu dalam proses pelayanan. Kehandalan merupakan kemampuan memberikan layanan yang dijanjikan dengan segera, akurat, dan memuaskan.

Pada penelitian ini, dimensi realibilitas ditentukan oleh indikator-indikator yaitu kecermatan pegawai dalam melayani pengguna layanan, BPBD Kabupaten Aceh Singkil memiliki standar yang jelas atau tidak, kemampuan pegawai dalam menggunakan alat bantu dalam proses pelayanan, keahlian pegawai dalam proses pelayanan.

Pelayanan publik di BPBD Kabupaten Aceh Singkil sudah menerapkan dimensi realibilitas. Penilaian kualitas publik yang sudah berjalan sesuai harapan masyarakat 
dalam dimensi ini antara lain kecermatan pegawai dalam melayani pengguna layanan, BPBD Kabupaten Aceh Singkil memiliki standar yang jelas atau tidak, kemampuan pegawai dalam menggunakan alat bantu dalam proses pelayanan. Namun pada pelaksanaannya masih terdapat indikator yang belum berjalan sesuai harapan masyarakat seperti keahlian petugas pemadam kebakaran dalam menggunakan alat bantu dalam proses penanggulangan kebakaran karena pengaruh dari petugas yang masih baru dan belum berpengalaman.

Dalam pelaksanaan pelayanan, masyarakat yang akan menilai bagaimana kinerja dan kemampuan pegawai dalam melaksanakan proses pelayanan. Keahlian petugas BPBD Kabupaten Aceh Singkil sangat diperlukan karena keahlian petugas ini menjadi salah satu penentu keberhasilan pemadaman kebakaran. Kemampuan petugas BPBD Kabupaten Aceh Singkil dalam menggunakan alat bantu pada proses pemadaman kebakaran masih belum semuanya menguasai, ditunjukkan dengan sedikitnya tenaga ahli yang mampu menggunakan alat bantu dengan maksimal.

Kemampuan dan sumber daya pegawai BPBD Kabupaten Aceh Singkil masih sangat terbatas. Permasalahan tersebut tentunya harus menjadi perhatian BPBD Kabupaten Aceh Singkil dalam mengoptimalkan kinerja petugas, karena standard operating procedure tidak akan berjalan sesuai dengan tujuan apabila tidak diimbangi dengan kehandalan atau kemampuan yang baik dalam melayani masyarakat.

Responsivitas (Ketanggapan), dimensi ini merupakan kemauan untuk membantu dan memberikan pelayanan yang cepat dan tepat kepada pengguna layanan, dengan penyampaian informasi yang berkaitan dengan keperluan pelayanan dengan jelas. Membiarkan masyarakat menunggu tanpa alasan yang jelas menyebabkan persepsi yang negatif dalam kualitas pelayanan. Secara singkat dapat diartikan sebagai kemauan untuk membantu pengguna layanan dengan baik dan cepat.

BPBD Kabupaten Aceh Singkil sudah berupaya menerapkan dimensi responsivitas beserta indikatornya. Penilaian kualitas publik yang sudah berjalan sesuai harapan masyarakat dalam dimensi ini antara lain merespon setiap pengguna layanan yang ingin mendapatkan pelayanan, petugas berusaha melakukan pelayanan dengan cepat, petugas melakukan pelayanan dengan tepat, petugas memberikan pelayanan dengan cermat, petugas melakukan pelayanan dengan waktu yang tepat, dan semua keluhan masyarakat direspon oleh petugas dari BPBD Kabupaten Aceh Singkil, walaupun dalam konteks pelaksanaannya belum dapat memenuhi standar operasional prosedur yang ditetapkan.

Daya tanggap adalah kesediaan pegawai pelayanan untuk membantu pengguna layanan dan menyelenggarakan pelayanan secara tepat waktu. Daya tanggap berkaitan dengan ketanggapan petugas yang akan meningkatkan kenyamanan masayarakat, ini sebagai salah satu pendorong keberhasilan pelayanan, daya tanggap pelaksanaan pelayanan akan mempengaruhi hasil kinerja sebab jika pelaksanaan pelayanan didasari oleh sikap, keinginan dan komitmen untuk melaksanakan pelayanan dengan baik, maka akan tercipta peningkatan kualitas pelayanan yang semakin baik.

Salah satu faktor utama kesuksesan dalam pelayanan adalah keramahan kepada masyarakat yang salah satu contohnya dengan tersenyum dan menyapa, dengan senyuman dan sapaan maka masyarakat akan merasa bahwa dirinya telah diperhatikan 
dan dari situ muncul dari dalam hati masyarakat bahwa masyarakat akan merasa nyaman dengan pelayanan yang diberikan oleh BPBD Kabupaten Aceh Singkil. Keramahan memang bukan aset, tetapi keramahan adalah kunci sukses untuk BPBD Kabupaten Aceh Singkil menjalin hubungan yang baik dengan masyarakat.

Dalam proses pelayanan publik tidak selalu berjalan sesuai dengan yang diharapkan, masih terdapat faktor-faktor yang menghambat proses pelayanan publik, diantaranya sumber daya pegawai yang masih kurang dan dibuktikan dengan ketiadaan pegawai yang benar-benar ahli dalam menggunakan alat bantu pemadaman yang pastinya sudah menguasai yang berkaitan dengan proses penanggulangan bencana kebakaran. Petugas pemadam kebakaran yang dimiliki oleh BPBD Kabupaten Aceh Singkil saat ini adalah mereka yang keahlian yang dimiliki khususnya pegawai dibagian pelayanan belum bisa optimal. Kegiatan pelayanan merupakan kegiatan yang berhadapan langsung dengan orang lain yaitu masyarakat yang membutuhkan pelayanan. Selain sumber daya pegawai faktor penghambat lain adalah sarana dan prasarana seperti sarana yang perlu peremajaan yang pada akhirnya menyebabkan petugas mengalami kesulitan dalam mengunakan sarana yang ada.

Selain faktor penghambat tentunya terdapat faktor pendukung diantaranya yaitu berupa semangat yang diberikan pegawai satu sama lain, berusaha untuk memberikan pelayanan yang terbaik bagi masyarakat yang membutuhkan pelayanan. Pegawai samasama saling menyemangati agar dapat memberikan pelayanan dengan keahlian masingmasing agar mewujudkan pelayanan yang prima. Selain sama-sama saling menyemangati, pegawai juga mengadakan rapat koordinasi atau semacam evaluasi setiap tiga bulan mengenai bagaimana pelayanan yang sudah dilakukan kepada masyarakat. Dengan mengadakan evaluasi maka para pegawai akan memberikan saran jika memang ada pegawai pelayanan yang masih belum bisa melakukan pelayanan dengan baik.

Faktor yang mendorong terwujudnya pelaksanaan yang berkualitas di BPBD Kabupaten Aceh Singkil adalah penanaman kesadaran melayani masyarakat dengan ikhlas sesuai dengan hati nurani. Kesadaran di sini maksudnya bahwa pegawai pelayanan mempunyai suatu tanggung jawab melayani masyarakat. Faktor pendukung lain adalah dengan adanya fasilitas yang membantu petugas dalam melaksanakan tugasnya melayani masyarakat yaitu berupa alat bantu walaupun belum semua petugas dapat menggunakannya dengan maksimal, namun sudah membantu untuk kelancaran proses pemadaman.

\section{SIMPULAN}

Berdasarkan tujuan penelitian yang ingin dicapai pada tesis ini yaitu menganalisis reliabilitas dan responsivitas Badan Penanggulangan Bencana Daerah (BPBD) Kabupaten Aceh Singkil dalam pelayanan penanggulangan bencana kebakaran di Kabupaten Aceh Singkil dan dari hasil penelitian serta pembahasan yang telah diuraikan, maka dapat ditarik kesimpulan:

Reliabilitas pelayanan pemadam kebakaran pada Badan Penanggulangan Bencana Daerah (BPBD) Kabupaten Aceh Singkil disimpulkan belum baik. Hal tersebut 
berdasarkan hasil wawancara dengan masyarakat yang menjelaskan bahwa: petugas pemadam kebakaran pada BPBD Kabupaten Aceh Singkil masih ada yang tidak cermat dan fokus dalam menangani bencana kebakaran, petugas pemadam kebakaran BPBD Kabupaten Aceh Singkil belum maksimal dalam melakukan pelayanan yang sesuai dengan standar, belum semua petugas pemadam kebakaran di BPBD Kabupaten Aceh Singkil memiliki keahlian yang baik dalam menggunakan alat bantu.

Responsivitas pelayanan pemadam kebakaran pada Badan Penanggulangan Bencana Daerah (BPBD) Kabupaten Aceh Singkil disimpulkan masih kurang baik dalam penanganan pelayanan bencana kebakaran di Kabupaten Aceh Singkil. Hal ini dilihat dari hasil wawancara dengan masyarakat yang menyebutkan: kecepatan pelayanan dari petugas pemadam kebakaran masih belum baik dikarenakan adanya kendala dengan akses jalan yang sempit, petugas pemadam kebakaran tidak percaya diri dalam melaksanakan tugasnya dan belum bisa memastikan berapa lama waktu yang dibutuhkan untuk penanganan bencana kebakaran, pihak pemadam kebakaran dalam hal ini di naungi oleh BPBD Kabupaten Aceh Singkil masih kurang menanggapi keluhan masyarakat, regulasi pada BPBD Kabupaten Aceh Singkil masih bersifatnya top down, namun petugas berusaha berkomunikasi dengan baik kepada korban melalui sikap empathy dalam bentuk pemberian bantuan kepada korban bencana kebakaran.

\section{DAFTAR PUSTAKA}

Aditya. (2011). “Analisis Pengaruh Kesadaran Merk, Keragaman Menu, Promosi, dan Kualitas Pelayanan Terhadap Keputusan Konsumen Untuk Membeli Pizza Hut DP Mall Semarang”. Skripsi. Semarang : Fakultas Ekonomi, Universitas Diponegoro.

Adzim, H.I. (2013). Pengertian dan Elemen Sistem Manajemen K3 (Keselamatan dan Kesehatan Kerja). Ahli K3 Umum. Diakses 20 oktober 2016.

Ahmad, F, (2018), Sinergitas Instansi Pemerintah Dalam Penanggulangan Kebakaran Hutan Dan Lahan Yang Terjadi Di Kabupaten Rokan Hilir: JOM Fisip Vol 5 No. 1 Tahun 2018

Anonim. (2007). Farmakologi dan Terapi. edisi 5, Departemen Farmakologi Terapeutik, Fakultas Kedokteran, Universitas Indonesia.

Berman, B, and Joel R. Evans, (2007). Retail Management, New Jersey: Prentice Hall.

Casmita. (2003). Kontribusi Kualitas Kinerja Pegawai Bagian tata Usaha dalam Menunjang Keberhasilan Pengelolaan Pendidikan di SLTP PPS. UPI. Bandung. Tidak Diteribitkan.

Dwiyanto, A, (2006), Mewujudkan Good Geovernance Melalui Pelayanan Public. Yogyakarta: UGM Press.

Feltrnger, B., Alcedo., Amman, W.J., Arnold, M., (2006). Living with Risk, "A Global Review of Disaster Reduction Initiatives". Buku terjemahan oleh MPBI (Masyarakat Penanggulangan Bencana Indonesia), Jakarta.

Gilbert, G.R. et.al. (2004). Measuring Customer Satisfaction in The Fast Food Industry: A cross-national Approach. The Journal of Services Marketing, 18.

Hadi, S. (2014). Penelitian Research. Yogyakarta: BPFE

Haifani, (2008), Manajemen Risiko Bencana (Studi Kasus Gempa Yogyakarta 27 Mei 2006). Jurnal Pusat pengkajian Sistem dan Teknologi Keselamatan

Hardiansyah. (2011). Kualitas Pelayanan Publik. Yogyakarta: Gava Media

Hardjosoedarmo, S, (2004), Total Quality Management, ANDI, Yogyakarta.

ISDR, (2004), Living with Risk "A Hundred Positive Examples of How People are Making The World Safer" United Nation Publication, Geneva, Switzerland, 2004.

Jurnal Kesehatan Masyarakat (e-Journal) Volume 3, Nomor 3, April 2015 (ISSN: 2356-3346) http://ejournal-s1.undip.ac.id/index.php/jkm

Koteng, M.Z., (2012), Efektifitas Program Perlindungan Anak Bagi Anak Yang Terpisah Pasca Bencana Tsunami Di Aceh, Jurnal Administrasi Publik : Public Administration Journal, 1 (1): 67-91

Lupiyoadi dan Hamdani, (2006). Manajemen Pemasaran jasa Edisi kedua. Penerbit Salemba Empat: Jakarta.

Macana, 2000. jurnal.umrah.ac.id/wp-content/uploads/gravity_forms/1.../Naskah-Publikasi3.pdf 
Napitupulu, E. \& Saragih, S. (2015). Developing Student-Centered Learning Model to Improve High Order Mathematical Thinking Ability. Canadian Center of Science and Education: Asian Social Science; Vol. 8, No. 6.

Nugraha, D.S. \& Sulastri, L (2018). Pengaruh Faktor Kompetensi Perencana, Faktor Data, Serta Faktor Anggaran terhadap Efektivitas Perencanaan Penanggulangan Bencana Alam di Kabupaten Sumedang. Jurnal Administrasi Publik : Public Administration Journal : Public Admnistration Journal (Public Administration Journal). 8 (2): 172-177

Nugroho. A. (2004). Analisis dan Desain Sistem Informasi. Andi. Yogyakarta

Ramadhan, I, dan Armansyah M., (2016). Peran Badan Penanggulangan Bencana Daerah Daerah Kota Medan dalam Penanggulangan Bencana Alam, JPPUMA: Jurnal Ilmu Pemerintahan dan Sosial Politik UMA (Journal of Governance and Political UMA), 4 (2): 173-181.

Rambe, A., \& Amir, P., Usman, T., (2016), Analisis Pemberdayaan Pegawai Badan Penanggulangan Bencana Daerah (Bpbd) Kota Medan, Jurnal Administrasi Publik, 6 (1): 20-30.

Ramli, S. (2010). Sistem Manajemen Keselamatan \& Kesehatan Kerja OHSAS 18001. Jakarta: Dian Rakyat.

Rangkuti, F (2009). Strategi Promosi yang Kreatif dan Analisis Kasus Integrated Marketing. Jakarta: Gramedia Pustaka Utama.

Ridwan, J. dan Sudrajat, A.S. (2009). Hukum Administrasi Negara dan Kebijakan Pelayanan Publik. Bandung: NUANSA.

Rinaldi, R., (2012), Analisis Kualitas Pelayanan Publik (Studi pada Biro Umum Sekretariat Daerah Propinsi Sumatera Utara), Jurnal Administrasi Publik : Public Administration Journal, 1 (1): 22- 34.

Rusli, (2015), Analisis Manajemen Pencegahan dan Penanggulangan Kebakaran Kota Parigi

Sirait, R.S.M.P., (2011), Analisis Pelayanan Publik Terhadap Administrasi Penerbitan Akta Kelahiran (Studi Pada Dinas Kependudukan Kota Medan), Jurnal Administrasi Publik : Public Administration Journal : Public Admnistration Journal, 1 (2): 232-249

Sugiyono. (2008). Memahami Penelitian Kualitatif. Bandung: CV. ALFABETA

Sutopo. H.B. (2002). Pengantar Penelitian Kualitatif. Surakarta: Universitas Sebelas Maret Press

Tarwaka, B.S.HA, Sudiajeng, L. (2012). Ergonomi Untuk Keselamatan, Kesehatan Kerja dan Produktivitas. Surakarta. UNIBA PRESS.

Tearfund, (2006), Mainstreaming Disaster Risk Reduction, A Tool for Development Organisation, Tearfund, 100 Church Road, Teddington, Middlesex, TW11 8QE, UK

Tjiptono, F. (2011). Service, Quality \& Satisfaction. Yogyakarta: Andi.

Tjiptono. F. (2008). Strategi Pemasaran. Edisi 3. Yogyakarta: Andi Offset

Winarsih, S.A \& Ratminto. (2012). Manajemen Pelayanan. Yogyakarta: Pustaka Pelajar

Zulkarnain, E. (2018), Efektivitas Kerja Pegawai UPT Pemadam Kebakaran Kijang pada Badan Penanggulangan Bencana Daerah (BPBD).

Damanik, M.V.R. Nasution, M.H.T. \& Sembiring, W.M. (2018). Hubungan Antara Pelayanan Pengurusan Sertifikasi Tanah dan Tingkat Kepuasan Masyarakat. PERSPEKTIF, 7 (1): 30-34

Hidayat, S. \& Nasution, I. (2013). Pelayanan Pencegahan dan Pemadam Kebakaran Pemerintah bagi Masyarakat dalam Mengatasi Musibah Kebakaran, JPPUMA: Jurnal Ilmu Pemerintahan dan Sosial Politik UMA (Journal of Governance and Political UMA), 1 (2): 176-191.

Nasution, F.R. \& Sinaga, R.S. (2014). Evaluasi Kinerja Pegawai Kantor Samsat dalam Pelayanan Bea Balik Nama Kendaraan Bermotor, JPPUMA: Jurnal Ilmu Pemerintahan dan Sosial Politik UMA (Journal of Governance and Political UMA), 2 (1): 1-17.

Efridawati \& Lubis, A.A. (2015). Kebijakan Pelayanan Izin Mendirikan Bangunan di Dinas Cipta Karya dan Pertambangan Deli Serdang, JPPUMA: Jurnal Ilmu Pemerintahan dan Sosial Politik UMA (Journal of Governance and Political UMA), 3 (1): 58-70.

PERATURAN PERUNDANGAN

Undang-Undang No. 25 tahun 2009 tentang Pelayanan Publik

Undang-Undang Nomor 24 Tahun 2007 tentang Penanggulangan Bencana

Peraturan Presiden Nomor 131 Tahun 2015 tentang Penetapan Daerah tertinggal Tahun 2015-2019

Peraturan Presiden Nomor 47 Tahun 2015 tentang Kementerian Pendayagunaan Aparatur Negara dan Reformasi Birokrasi

Peraturan Menteri Dalam Negeri Nomor 114 Tahun 2018 tentang Standar Teknis Pelayanan Dasar Pada Standar Pelayanan Minimal Sub Urusan Kebakaran Daerah Kabupaten/Kota

Peraturan Menteri Negara PAN dan RB Nomor 38 Tahun 2012 tentang Pedoman Penilaian Kinerja Unit Pelayanan Publik.

Peraturan Bupati Aceh Singkil Provinsi Aceh Nomor 51 Tahun 2016 tentang Kedudukan, Susunan Organisasi, Tugas Fungsi dan Tata Kerja Badan Penanggulangan bencana Daerah Aceh Singkil 